\title{
REFLEKSI HUKUM ZAKAT DIGITAL PADA BAZNAS DALAM RANGKA PENINGKATAN KESEJAHTERAAN MUSTAHIK
}

\author{
Pertiwi Utami ${ }^{1}$, Tulus Suryanto ${ }^{2}$, Ruslan Abdul Ghofur ${ }^{3}$, M. Nasor ${ }^{4}$ \\ ${ }^{1}$ Magister Ekonomi Syariah Pascasarjana UIN Raden Intan Lampung \\ ${ }^{2}{ }^{\& 3}$ Fakultas Ekonomi dan Bisnis UIN Raden Intan Lampung \\ ${ }^{4}$ Fakultas Dakwah UIN Raden Intan Lampung \\ E-mail: utamipertiwi89@gmail.com
}

\begin{abstract}
Abstrak
Peneliti melakukan kajian pengetahuan hukum digital zakat pada Badan Amil Zakat Nasional (BAZNAS) Pusat di Indonesia. Penelitian ini bertujuan untuk mengetahui bagaimana pendekatan hukum Islam terhadap penggunaan layanan digital zakat dan bagaimana implementasi prinsip-prinsip pengelolaan yang baik pada manajemen zakat digital. Dengan menggunakan metodologi hukum Islam, peneliti ingin memberikan wawasan baru dari segi kajian hukum ekonomi dan keuangan syariah dengan pendekatan tersebut. Dari hasil analisis dan pembahasan, mengungkapkan bahwa hukum penggunaan teknologi digital sendiri diperbolehkan dan tidak bertentangan dengan prinsip-prinsip syariah, selama serta tidak mengandung unsur-unsur kemudharatan bagi penggunanya. Sedangkan implementasi prinsip-prinsip syariah pada digital zakat baik penghimpunan dan penyaluran zakat sudah cukup baik.
\end{abstract}

Kata kunci: hukum islam; zakat; teknologi digital.

\begin{abstract}
Researchers conducted a legal study of zakat digital at the National Amil Zakat Agency (BAZNAS) in Indonesia. This study aims to find out how to approach Islamic law on the use of digital zakat services and how to implement the principles of good management in digital zakat management. By using the methodology of Islamic law, researchers want to provide new insights in terms of the study of Islamic economic and financial law with that approach. From the results of the analysis and discussion, revealed that the law of the use of digital technology itself is allowed and does not conflict with Islamic principles, as long as it does not contain elements of harm to its users. Whereas the implementation of sharia principles in digital zakat both collection and distribution of zakat is quite good.
\end{abstract}

Keywords: islamic law; zakat payment; digital technology. 


\section{Pendahuluan}

"Digitalisasi Zakat memberikan manfaat besar yaitu digital finance membuat pengumpulan dan pengelolaan zakat lebih efisien, transparan dan masif, mengurangi biaya dalam transaksi, mampu menjangkau masyarakat termasuk generasi milenial, dan mampu meningkatkan keamanan pengumpulan dan pengelolaan zakat secara nasional." 1 "Zakat memiliki potensi yang sangat signifikan dalam meningkatkan kesejahteraan masyarakat." 2 Dengan kata lain, pemberdayaan zakat yang sesuai dengan prinsip-prinsip syariah dan implementasinya selayaknya menjadi prioritas utama. Selain itu, "Perkembangan teknologi yang memasuki Era transformasi Teknologi 4.0, diharapkan lembaga zakat mampu menerapkan efisiensi dan efektivitas pada pelaksanaan operasional pengelolaan zakat."3

BAZNAS terus melakukan inovasi baru untuk mendukung kinerja dalam penghimpunan da pengelolaan zakat. Adanya pekembangan teknologi seperti sistem digit dan blockhain telah digunakan terutama penghimpunan zakat, pengelolaan zakat, penyaluran serta sebagai sarana edukasi zakat BAZNAS. ${ }^{4}$ Dalam aktivitas pengelolaanya zakat, tentunya dibutuhkan kajian hukum Islam untuk mempertegas boleh tidaknya penggunaan teknologi terutama zakat payment berbasis Fintech. Bahkan saat ini perkembangan teknologi digital telah berkembang sedemikian rupa dan digunakan sebagai salah satu model program penghimpunan dan penyaluran zakat seperti kurban digital dan ATM beras oleh BAZNAS. ${ }^{5}$

“Pada Tahun 2018 terjadi penurunan dampak zakat. Indeks kemandirian menjadi nilai terendah dalam Indeks Kesejahteraan BAZNAS (IKB), oleh sebab itu lembaga zakat memprioritaskan program-program unggulan untuk menghimpun dan menyalurkan zakat kepada mustahik." ${ }^{6}$ Dan ditahun 2019

${ }^{1}$ Wahyu Syuryana \& Dwi Murdaningsih, 2018, Alasan Pentingnya Digitalisasi Zakat, Khazanah, Diakses dari https://www.republika.co.id/berita/dunia-islam/ wakaf /18 /11 /15/pi83kx368-alasan-pentingnya-digitalisasi-zakat, Pada tanggal 2525 juli 2019.

${ }^{2}$ Divisi Riset dan Kajian Pusat Kajian Strategis BAZNAS, Dampak Zakat Terhadap Kesejahteraan Mustahik: Evaluasi Program Zakat Produktif 2018, ed. by Pusat Kajian Strategis BAZNAS (Jakarta Pusat, 2019).

${ }^{3}$ Natalia Monjelat and Siti Jamila, 'Analisis Efisiensi \& Efektivitas Zakat Payroll System Dan Zakat Digital Terhadap Penerimaan Zakat Pada BAZNAS Periode 2016-2017', Director, 2018, 1-104. https://doi.org/10.22201/fq.18708404e.2004.3.66178.

${ }^{4}$ Pusat Kajian Stategis (PUSKAS) BAZNAS, Outlook Zakat Indonesia 2019, (Pusat Kajian Strategis-Badan Amil Zakat Nasional (PUSKAS BAZNAS), 2019). hlm. 3.

${ }^{5}$ Pusat Kajian Stategis (PUSKAS) BAZNAS, Outlook Zakat Indonesia 2020, (Pusat Kajian Strategis-Badan Amil Zakat Nasional (PUSKAS BAZNAS).

${ }^{6}$ Ibid., hlm. 22. 
terjadi peningkatan penghimpunan zakat sebesar $15 \% .{ }^{7}$ Walaupun terjadi peningkatan namun secara statistik masih jauh dari total potensi penerimaan zakat nasional.

"Dari segi Hukum syariah, kajian mengenai perangkat peraturan terinci yang bersifat amaliah dan harus diikuti sebagaimana ketentuan Islam disebut figh. Sedangkan, kajian mengenai ketentuan, tata cara serta usaha yang sistematis dalam menghasilkan perangkat peraturan terinci disebut ushul fiqh" ${ }^{8}$ Kata 'sumber' dalam kaidah fiqh ditujukan untuk Al Quran dan As sunah karena keduanya merupakan wadah yang dapat ditimba hukum syara'. Tidak termasuk untuk 'ijma' dan qiyas karena keduanya bukanlah yang dapat ditimba dalam norma syariah. Namun kata 'dalil' dapat digunakan untuk Al Quran dan As sunah, juga dapat digunakan untuk ijma' dan qiyas. Karena kesemuanya menuntun kepada penemuan hukum Allah. ${ }^{9}$

Perkembangan ekonomi dan keuangan berdasarkan prinsip-prinsip syariah telah ada sejak zaman Para Nabi. Dari catatan sejarah, pemenuhan kebutuhan manusia baik dalam usaha, etika bisnis dan tata kelolanya telah diberikan petunjuk yang bersumber dari Al Quran dan As sunah. Di dalamnya terdapat segala perintah Allah dalam berbagai dimensi. Oleh karena itu penting untuk melakukan penelitian hukum Islam dalam aktivitas ekonomi dan keuangan sebagai bentuk pengembangan ilmu ekonomi yang bersumber dari nilai-nilai Islam yang dapat membawa kepada kemaslahatan umat manusia.

Kehadiran hukum syariah dewasa ini semakin banyak menghadapi berbagai tantangan. Prinsip-prinsip syariah yang terdapat dalam konsep ekonomi dan keuangan mengharuskan secara aktif memecahkan berbagai persoalan dan gejala ekonomi-sosial yang ada di masyarakat dalam upaya memenuhi kewajiban sebagai khalifah dan menuntut hak sebagai makhluk sosial. Tuntunan syariah dalam ekonomi dapat dijawab melalui berbagai pendekatan. Pendekatan yang dimaksud adalah cara pandang atau paradigma yang terdapat dalam bidang ekonomi yang selanjutnya digunakan untuk memahami prinsip-prinsip syariah. Prinsip-prinsip syariah yang terdapat dalam ajaran Islam sebagaimana realitas dari keagamaan yang secara khusus membahas aturan-aturan atau hukum yang diimplementasikan dalam ekonomi memiliki nilai kebenaran sesuai dengan kerangka paradigmanya.

${ }^{7}$ P. (Pengelola I. dan D. BAZNAS, "Laporan Perkembangan Zakat," 2019. [Online]. Available: https://pid.baznas.go.id/.

${ }^{8}$ Andri Soemitra, Bank Dan Lembaga Keuangan Syariah Edisi Kedua, Kencana, Depok, 2017. hlm. 35.

${ }^{9}$ Amir Syarifuddin, Ushul Fiqh, Kencana, Bandung, 2014. 
Dewasa ini, nilai-nilai Islami semakin tergerus perkembangan zaman. Budaya kebaratan semakin menggurita dalam segala aspek dan dimensi kehidupan. Mulai dari gaya hidup, trend, dan lingkungan bermasyarakat. Perlu diketahui bahwa prinsip-prinsip syariah dalam ekonomi telah banyak digunakan dalam sistem keuangan syariah. Namun syariah tidak berarti akan mempengaruhi perubahan terhadap paradigma dan lingkngan dimana ekonomi syariah diterapkan. Bisa saja, suatu negara atau pemerintahan memiliki sistem keuangan syariah yang baik dan dapat menopang perekonomian, tetapi tidak dapat dipastikan bahwa nilai-nilai Islam dalam masyarakatnya benarbenar dapat dipertahankan sesuai ketentuan ajaran agama Islam. Karena ekonomi syariah adalah aturan hukum dan prinsip dalam sebuah aktivitas ekonomi berdasarkan tuntunan Al Quran dan As sunah bukan tentang tauhid, hikmah, dan ibarat sebagaimana dalam ajaran Agama Islam secara menyeluruh. Yang dimaksud dengan nilai-nilai Islami sebagaimana nilai Al quran dalam empat aksioma etika yang disebut tauhid, adil, kebebasan bertindak, dan pertanggung jawaban yang disebut dengan prinsip-prinsip fundamental. ${ }^{10}$

Dalam konteks pendekatan hukum Islam, teknologi digital dalam zakat masih tergolong penelitian yang belum banyak dilakukan oleh peneliti terdahulu. Kajian ini sangat penting untuk melihat perkembangan Informasi dan Teknologi terutama teknologi payment digital dalam Lembaga Keuangan Syariah non komersial yang saat ini sedang berkembang pesat. Bukan hanya itu, teknologi digital pada lembaga zakat menjadi suatu kajian menarik ketika didalamnya terdapat berbagai tema terkait berbagai persoalan dan tantangan pengelolaan zakat oleh BAZNAS.

Muhammad menjelaskan bahwa terdapat langkah-langkah yang diambil dalam bangunan teori [ekonomi] Islam yang digunakan didasarkan pada dua aspek hukum,yaitu hukum syariah dan hukum thabi'i dalam masyarakat." 11 Amir Syarifuddin menjelaskan bahwa, "Kajian mengenai hukum Islam mengandung dua bidang pokok yang masing-masing luas cakupannya, yaitu: 1) kajian mengenai perangkat peraturan terinci yang bersifat amaliah dan harus diikuti umat Islam dalam kehidupan beragama, atau disebut Fiqh dalam artian khusus; dan 2) kajian yang membahas ketentuan serta cara dan usaha yang sistematis dalam menghasilkan perangkat peraturan yang terinci atau disebut ushul fiqh atau dalam arti lain sistem metodologi fiqh. Fiqh dan Ushul Fiqh merupakan dua bahasan yang terpisah, akan tetapi saling berhubungan dan

${ }^{10}$ S.N.H. Naqvi, Islamic Economic Methodology in A.R Moten and B. Shari (eds). Nature and Methodology of Islamic Economic, Nigeria: Bayero University, 1981.

11 Muhammad, Metodologi Penelitian Ekonomi Islam: Pendekatan Kuantitatif, Rajawali Pers. Jakarta, 2008, hlm. 33. 
berkaitan." 12 Sedangkan Nata mengungkapkan bahwa pendekatan normatif dalam memahami ekonomi sebagai suatu upaya memahami pemenuhan kebutuhan/ekonomi dengan menggunakan kerangka IImu ketuhanan yang bertolak pada suatu keyakinan dalam diri bahwa wujud empirik dari suatu keagamaan dianggap sebagai yang paling besar. Dalam agama Islam yaitu kewajiban melaksanakan perintah-Nya dan menjauhi larangan-Nya. Ciri khas dari pendekatan teologis normatif dalam ekonomi syariah adalah pandangan yang kritis terhadap berbagai gejala ekonomi yang menghambat perintah-Nya dan menyelamatkan manusia serta nilai kemanusian. ${ }^{13}$

Pendekatan teologis normatif tidak dapat digunakan untuk memahami ekonomi syariah secara keseluruhan tetapi bisa untuk memahami ekonomi berdasarkan nilai-nilai agama Islam. Qatadah, menurut yang diriwayatkan alThabari, menggunakan kata syariah kepada hal-hal yang menyangkut kewajiban, had, perintah, dan larangan; tidak termasuk didalamnya 'akidah/tauhid', hikmah, dan ibarat yang tercakup dalam agama. Kata Syariah lebih khusus dari agama. Syariah adalah hukum amaliah yang berbeda menurut perbedaan Rasul yang membawanya dan setiap yang datang kemudian mengoreksi yang datang lebih dahulu. Berbeda dengan dasar agama Islam, yaitu 'akidah/tauhid', tidak berbeda antara Rasul yang satu dengan lainnya. ${ }^{14}$

Tinjauan berbagai literatur dijelaskan bahwa, "Fintech dalam lembaga keuangan syariah terus berkembang," ${ }^{15}$ Dana zakat memiliki peran yang cukup baik terhadap pemberdayaan mustahik khususnya dalam aspek ekonomi." ${ }^{16}$ Salah satu penelitian yang menarik adalah, "Penerapan konsep mardhatillah (untuk mendapatkan keberkahan) pada zakat payment dengan memanfaatkan tegnologi digital," ${ }^{17}$ Selalu ada peluang bagi lembaga amil zakat untuk menggunakan teknologi keuangan. ${ }^{18}$ Penelitian yang dilakukan Rachman dan Salam, "Ada berbagai ancaman dan penyalahgunaan menggunakan teknologi keuangan yang terus mengalami perkembangan dan kemajuan. Penguatan dan pengawasan pengelolaan zakat menggunakan langkah-langkah strategis yang

${ }^{12}$ Amir Syarifuddin, 2014, Op. ,cit. hlm. 38.

13 Abuddin Nata, Metodologi Studi Islam, Ed. Revisi Cet-21, Rajawali Pers, Jakarta, 2014.

${ }^{14}$ Amir Syarifuddin, 2014, Op. , cit

${ }^{15}$ Djafri F. LSE-HBKU Workshop | February 23, 2017 Applying Hiyal \& Makharij and other Islamic Principles. 2018; (February 2017).

${ }^{16}$ Prahesti DD, Pemberdayaan Usaha Kecil dan Mikro Melalui Dana Zakat Produktif, Acad J Homilet Stud. 2018;12(1):141-160, doi:10.15575/idajhs.v12i.190.

17 Doktoralina CM, Bahari Z, Abdullah SR. Mobilisation of Income Zakat Payment In Indonesia. 2018;3(2):189-204

${ }^{18}$ D. Friantoro, Zaki K. Do We Need Financial Technology for Collecting Zakat ? 2018. 
terstruktur dengan memanfaatkan Fintech dalam manajemen zakat diperuntukan untuk mewujudkan percepatan pembangunan pengelolaan zakat. Proses ini meliputi aspek kepatuhan hukum perdata, kepatuhan hukum syariah, akuntabilitas, dan struktur keamanan."19 Penelitian Beny menyatakan tentang dibutuhkannya pelatihan dan pengembangan cybersecurity, selain daripada itu penting untuk mengatasi resiko penipuan yang terkait dengan etika dan integritas manusia." 20

Fintech memberikan kemungkinan untuk struktur organisasi dan model bisnis yang inovatif dan fleksibel untuk menaikkan inklusi keuangan, selain itu juga aplikasi Fintech untuk layanan keuangan harus memiliki aturan hukum bukan hanya dari yurisdiksi tetapi juga penekanan pada tata kelola syariah. ${ }^{21}$ Meskipun teknologi informasi telah diadopsi pada manajemen zakat, tidak ada regulasi dan aturan standar terkait. Sehingga diperlukan pedoman hukum dan jaminan dari pemerintah untuk mendorong peningkatan pengelolaan zakat, meningkatkan inovasi, dan menumbuhkan kepercayaan masyarakat. Prosesproses ini mencakup aspek kepatuhan hukum, kepatuhan syariah, akuntabilitas, dan struktur keamanan. Ini dapat diwujudkan melalui integritas kelembagaan, sistem pengembangan teknologi, standardisasi, sertifikasi, dan pendidikan. $^{22}$

Meskipun ada kemajuan dalam teknologi, sebuah penelitian mengungkapkan bahwa, "Media utama yang digunakan untuk mendapatkan informasi zakat adalah dari mulut ke mulut. Temuan penelitian ini dapat bermanfaat bagi lembaga zakat untuk mengevaluasi efisiensi pengelolaan zakat dalam memenuhi kebutuhan penerima zakat." ${ }^{23}$ Studi yang dilakukan terhadap lembaga-lembaga zakat Brunei menyoroti fasilitas inklusif keuangan dalam praktik mereka dan membantu memenuhi motif tabungan penerima zakat terutama untuk masyarakat menegah ke bawah. ${ }^{24}$

${ }^{19}$ Rachman MA, Salam AN. The Reinforcement of Zakat Management through Financial Technology Systems. Int Zakat. 2018;3(1):57-69. http://ijazbaznas. com/index.php/journal/article/view/68/32.

20 Smith A. Emergence of Fintech and cybersecurity in a global financial centre: strategic approch by a regulator. J Financ Regul Compliance. 2014;16(2). doi:10.1108/jfrc.2008.31116baa.001

${ }^{21}$ Fares Djafri, 'Fintech and Islamic Finance: Aplying Hiyal \& Makhrij and Other Islamic Principles', 2018, 1-10 . https://www.researchgate. net/ publication /325333580\%0AFintech.

${ }^{22}$ Rachman and Salam.

${ }^{23}$ Ahmad RAR, Othman AMA, Salleh MS. Assessing the Satisfaction Level of Zakat Recipients Towards Zakat Management. Procedia Econ Financ. 2015;31(15):140-151. doi:10.1016/s2212-5671(15)01141-7

${ }^{24}$ Ak Md Hasnol Alwee Pg Md, 'Integrating Financial Inclusion and Saving Motives into Institutional Zakat Practices: A Case Study on Brunei', International Journal of Islamic and Middle Eastern Finance and Management, 8.2 (2015), $150-70$. https: / /doi.org/10.1108/17538391111144515. 
Dalam khazanah pemikiran hukum Islam, berbagai faktor yang menghambat ataupun mendukung realisasi ekonomi dengan prinsip-prinsip ajaran Islam seperti keadilan dan larangan Magrib (maysir, gharar, dan riba). Dengan demikian, hukum syariah dalam aktivitas ekonomi dan keuangan bukan hanya berhenti pada pemahaman mengenai ajaran agama, tetapi juga mendorong terjadinya transformasi ekonomi-sosial.

Rahmat mengemukakan lima alasan keterkaitan nilai-nilai Islami yang terdapat dalam ekonomi dan keuangan syariah sebagaimana berikut ini; Al Quran dan As sunah, proporsi hukum Syariah ini berkenaan dengan urusan muamalah. Menurut Ayatullah Khomaeni menyatakan bahwa perbandingan antara ayat-ayat ibadah dan ayat-ayat yang berkaitan dengan kehidupan sosial adalah satu berbanding seratus-untuk satu ayat ibadah, terdapat seratus ayat muamalah (masalah sosial); Bahwa ditekankan masalah muamalah ialah adanya kenyataan bahwa urusan ibadah bersamaan waktunya dengan urusan muamalah yang sangat penting, maka ibadah boleh diperpendek atau ditangguhkan (bukan ditinggalkan), melainkan dikerjakan sebagaimana yang telah ditentukan dalam agama; Bahwa ibadah yang mengandung segi kemasyarakatan diberi ganjaran lebih besar daripada ibadah yang bersifat perseorangan; Dalam Islam terdapat ketentuan bila urusan ibadah dilakukan tidak sempurna atau batal, karena melanggar pantangna tertentu, maka kifaratnya (tebusannya) adalah melakukan sesuatu yang berhubungan dengan masalah sosial; Nilai-Nilai Islam dalam Ekonomi Syariah juga mengajarkan tentang amal baik seperti bersedekah dan wakaf dalam bidang kemasyarakatan. ${ }^{25}$

\section{Permasalahan}

Penelitian ini bertujuan untuk meneliti dua bahasan pokok pengelolaan amil zakat dalam pendekatan hukum Islam. Agar menghindari kemungkinan kesalahpahaman penafsiran tujuan peneltian ini dan mengingat luasnya ruang lingkup bahasan terutama tata kkelola dan manajemen zakat terutama karena telah adanya peraturan perundang-undangan Nomor 23 tahun 2011 tentang pengelolaan zakat dan Fatwa MUI tentang Pelaksanaan dan Pengelolaan Zakat. Maka perumusan masalah penelitian adalah Pertama, Bagaimanakah praktik zakat digital pada BAZNAS Pusat ? Kedua, Bagaimana hukum Islam memandang dari segi Ilmu ‘aqidah' dan ilmu 'syariah' terhadap penggunaan zakat berbasis digital ?

\footnotetext{
${ }^{25}$ Jalauddin Rahmat, Islami Alternatif, Bina Aksara, Bandung, 1991.
} 


\section{Metodologi Penelitian}

Desain penelitian kualitatif menggunakan analisis data sekunder dari berbagai sumber literatur paling up-date dipilih oleh peneliti untuk mengungkapkan hasil pembahasan. Fleksibilitas desain penelitian ini adalah adanya kemudahan pada saat ditemukan gagasan atau wawasan baru. Dengan menggunakan pendekatan Hukum Islam, peneliti akan mengungkapkan wawasan baru mengenai hukum dalam Zakat Digital di Lembaga Zakat BAZNAS. Prinsip-prinsip syariah digunakan untuk mengkaji bagaimana prinsip tata kelola lembaga dapat berkontribusi guna strategi lembaga zakat untuk memperkuat struktur kelembagaan dan pemberdayaan zakat dalam menjawab tantangan digital dimasa mendatang. Bahan pustaka hukum yang dipergunakan untuk penelitian pengelolaan zakat ini terdiri dari: Bahan Hukum Primer (primary sources of authorities) dan bahan hukum sekunder.

\section{Pembahasan}

\section{Implementasi Teknologi Digital pada Badan Amil Zakat Nasional Pusat}

Teknologi digital telah dipergunakan dalam praktik pengelolaan dan penghimpunan zakat, penyaluran zakat, serta sebagai sarana edukasi zakat. Teknologi blockchain dipergunakan BAZNAS untuk meningkatkan transparansi lembaga pengelolaan zakat bekerjasama dengan Desto dalam aplikasi iZakat. Sedangkan dalam bidang penghimpunan terdapat tiga platform yang disediakan untuk menghimpunan dana ZIS (zakat, infaq, dan sadaqah) sebagaimana pada tabel dibawah ini.

Tabel 1.1. Platform Digital Zakat Bidang Penghimpunan BAZNAS Tahun 2019

\begin{tabular}{|c|c|c|c|}
\hline No & Platform & Ketentuan & Praktik \\
\hline 1 & Internal platform & $\begin{array}{l}\text { Platform yang } \\
\text { dikembangkan OPZ } \\
\text { sendiri dalam bentuk } \\
\text { website atau aplikasi } \\
\text { BAZNAS }\end{array}$ & $\begin{array}{l}\text { a) Menyediakan laman } \\
\text { pembayaran zakat pada } \\
\text { situs webnya } \\
\text { (baznas.go.id/zakat } \\
\text { sekarang); dan } \\
\text { b) aplikasi Muzaki Corner }\end{array}$ \\
\hline 2 & $\begin{array}{l}\text { Eksternal } \\
\text { platform }\end{array}$ & $\begin{array}{lr}\text { Platform yang } \\
\text { disediakan mitra OPZ } \\
\text { untuk menghimpun } \\
\text { dana ZIS dengan } \\
\text { menggunakan kanal } \\
\text { pembayaran zakat } \\
\text { berbasis teknologi }\end{array}$ & $\begin{array}{l}\text { a) e-commerce } \\
\text { (Tokopedia, Blibli, } \\
\text { BukaLapak, Kaskus, } \\
\text { MatahariMall, dan } \\
\text { Lazada) } \\
\text { b) online (bit.ly/zakat- } \\
\text { Kitabisa dan aplikasi }\end{array}$ \\
\hline
\end{tabular}




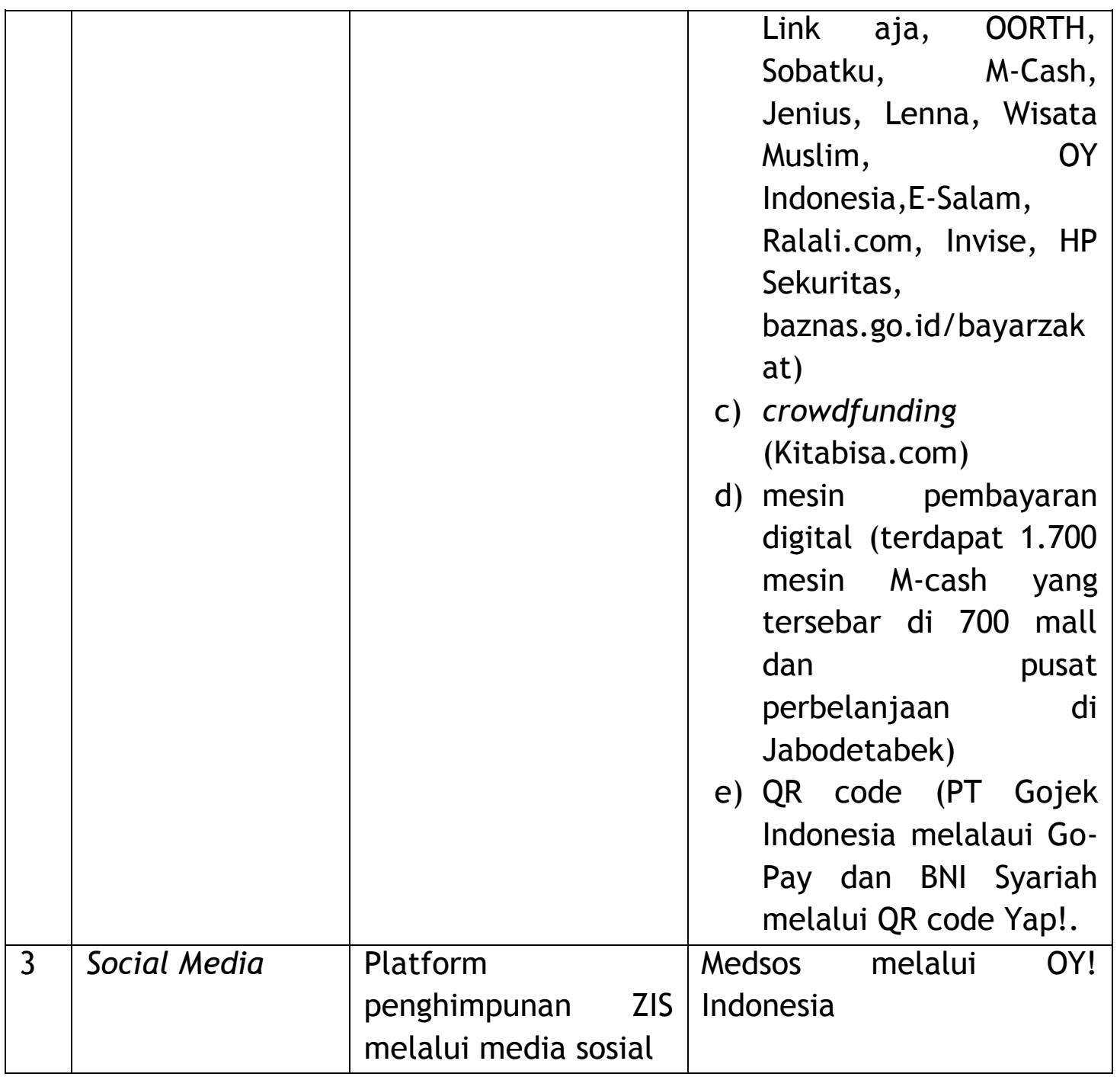

Berdasarkan dokumentasi BAZNAS, platform digital BAZNAS hingga november 2019 telah berkembang menjadi lima platform besar yang dipegang oleh lima orang digital fundraising. Total platform exiting adalah 41 platform dan total platform on procces sebanyak 8 platform.

Mitra digital BAZNAS pada commercial platform akan menghimpun zakat untuk kemudian diserahkan atau ditransfer kepada divisi digital zakat. Aktivitas penghimpunan digital zakat melalui platform ini dilakukan sesuai dengan jumlah nominal tertentu dalam jangka waktu perminggu/perbulan tergantung pada besar kecilnya penghimpunan zakat. Untuk muzaki yang berada di luar negeri, paypol dapat digunakan sebagai media digital zakat. Zakat yang dibayar dalam bentuk dollar (\$) yang nantinya akan dirupiahkan. Bahkan untuk zakat berupa saham dan reksadana sudah tersedia. Ini dilakukan semata untuk mempermudah muzaki dalam membayar zakat, sehingga tidak ada alasan lagi untuk tidak membayar zakat bagi umat muslim. 


\section{Zakat Digital pada Badan Amil Zakat Nasional dalam Perspektif Hukum Islam dan Keuangan Syariah Dalam Upaya Kesejahteraan Mustahik}

Dikutip dari Utami et al, ${ }^{26}$ "Berdasarkan teori-teori hukum Islam dalam pespektif ekonomi dan keuangan syariah, diperoleh sembilan kaidah itu adalah: ${ }^{27}$ pertama, Teori Niat (Nadharariyad An-Niyat). Dalam kaidah fiqh disebutkan, “ al-ibratu fi al'uqudi li al-maqashidi wa al-ma'ani lal $i$ al-fadzi wal mabani", akad transaksi adalah maksud dan niat, bukan lafadz dan statement. Hakikatnya semua perbuatan adalah diperbolehkan jika diniatkan dengan benar,maka hal tersebut bernilai ibadah dan mendatangkan pahala. Niat didedikasikan sebagai awal dalam pencapain tujuan. Baik dalam pendistribusian zakat ataupun pengelolaannya harus memenuhi syarat tertentu. Asmawi dalam buku Ekonomi Syariah yang ditulis Pradja menjelaskan tentang tiga syarat berikut: (a) lafazh yang diutarakan harus memiliki makna luas menurut pemakaian bahasa Arab, (b) ada kesetaraan pada makna lafadz secara lahiriah dengan niat dan ada tanda-tanda yang menguatkan posisi niat (maksud tujuan) maka niat tersebut tidak bisa dijadikan sandaran hukum, dan (c) Konsekuensi hukum yang dilahirkan atas niat lebih rendah (ringan) deretannya dari makna lahiriah lafadz (ucapan), apabila tidak demikian, niat itu tidak diperdulikan. ${ }^{28}$

Kedua, teori Ungkapan Keinginan (Nadhariyah Al-Ta'bir Al-'Iradat). Asmawi juga mengatakan bahwa, "Keinginan merupakan sesuatu yang tidak dapat diketahui, tetapi dapat dilihat tanda-tandanya seperti dalam perkataan,isyarat ataupun ucapan.Ketentuan hukum harus berdasarkan keinginan hati bukan berdasakan ucapan." ${ }^{29}$ Sebuah kaidah mengatakan, “ I'mali al-kalam aula min ihmaalihi" (Memegang perkataan orang lebih utama daripada menafikannya).

Ketiga, Teori Pemeliharaan Kemaslahatan (Nadhariya Al-Maslahah). Maslahah pada umumnya merupakan suatu nisbi karena banyak maslahah yang didalamnya terkadang mengandung unsur mafsadat,begitu juga sebaliknya. Dalam kaidah fiqhiyah: "la dharara wala dhirara",(dilarang menyebabkan kemudharatan dan dilarang membalas kemudharatan dengan sejenisnya).Misalnya: (a) Larangan penipuan, pemalsuan dan ketidakpastian

${ }^{26}$ Pertiwi Utami, et al. Management of Zakat Payment Based on Fintech for the Good Corporate Governance Improvement. Eastern Journal of Economics and Finance, 4(2), 2019, hlm. 41-50.

27 Juhaya S. Pradja, Ekonomi Syariah, CV. Pustaka Setia, Bandung, 2012, hlm. 143151.

${ }^{28}$ Juhaya, Ibid. hlm. 19.

${ }^{29}$ Ahmad Nuryadi Asmawi, Philosofi of Islamic Law of Trasaction (in Legal Fiqh Maxim) Modul of Certified Islamic Financial Analyst (CIFA) Program Pascasarjana UIN SGD in Coorperation with Muamalah Institute, hlm. 17. 
(gharar), (b) Larangan kepada orang yang tidak sempurna akalnya (safih) dari membelanjakan hartanya. Larangan kepada al-Mufti al-Majiri untuk tidak memberikan fatwa kepada orang, )

Keempat, Teori Hukum Asal (Nadhariyat Al-Akhadzi bi Al-Istisshab). Hukum asal (istishab) sama halnya meneruskan berlakunya hukum syara' yang telah tetap pada waktu terdahulu mengenai suatu masalah hingga ada dalil lain yang menyatakan hilangnya ketentuan tersebut. Dalam kaidah, "al-yakinu la yuzalu bi ass-syaq" (suatu ketentuan hukum yang telah diyakini keberadaannya tidak dapat dihilangkan dengan semata-mata). Menurut ahli ushul fiqh, pengindaraan terbagi lima tingkatan,yaitu: (a) Yakin; sesuatu yang akan menimbulkan ketenangan di dalam hati karena adanya kepastian, (b) Syak; keragu-raguan, adalah posisi dimana kita tidak cenderung pada yang kiri ataupun pada yang berada dikanan, (c) Dzan kuat; salah satu dari kedua belah sisi lebih kuat dari pada sisi lainnya, (d) Dzan kuat; salah satu dari sisi lebih kuat, tetapi kekuatan tersebut tidak serta merta mengalahkan sisi lain secara keseluruhan atau mutlak, dan (e) Wahm; merupakan sisi yang lemah dan dikalahkan oleh sisis lainnya. Artinya, sisi dzan saling bertentangan dengan sisi wahm.

Kelima, teori Batasan-batasan ljtihad (Nadhariyat Dhawabith Alljtihad). Ijtihad diartikan mengerahkan segala tenaga dan pikiran untuk mendapatkan kesimpulan hukum syara' pada masalah tertentu dengan mengkaji dan meneliti nash-nash Al Quran dan As sunah sesuai kaidah-kaidah bahasa Arab atau menggunakan (analogi) setelah mengetahui alasan (illat) sebab hukum. Ijtihad terbagi dua bagian. Pertama, ijtihad memahami makna nash (teks Al Quran dan As sunah), dilakukan apabila makna teks Al Quaran dan As sunah kurang jelas. Kedua, ijtihad degan jalan menempelkan hukum baru dengan hukum yang telah ditetapkan nash (teks Al Quran dan As sunah) melalui jalur qiyas (analogi) masalah atau selain keduanya dari jenis -jenis dalil kontemporer yang dipergunakan dalam batasan ljtihad. Seperti, dalil urut (adat) dan istishab. Keenam, Teori Perwalian (Nadhariyat Al-Walayah). Perwalian yaitu otoritas yang diberikan syariat Islam kepada seseorang untuk melakukan tindakan yang mengikat sebagai tindakan perwalian yang memiliki batasan dan ketentuan hukum. Dalam kaidah fiqhiyah: " tasarufi al-imani 'ala al-ra'iyati munawathi bi al-maslahah",(kebijakan pemimpin [imam] terhadap rakyatnya harus didasarkan kemaslahatan).

Ketujuh, Teori Syarat Jaliyah dalam Akad. Syarat jaliyah merupakan syarat transaksi akad yang sengaja disebutkan oleh kedua belah pihak sebagai tambahan atas ketentuan yang ditetapkan syariat. Dalam kaidah fiqih: "yalzumu mura'atu syarthi biqadri 'imkani",(wajib memenuhi syarat sesuai dengan kemampuan).Dengan ketentuan, apabila syarat yang diajukan sudah 
menjadi adat dan kebiasaan,syarat tersebut bisa diterima akan tetapi, apabila sebaliknya maka syarat tersebut tidak diterima dan hukum transaksinya fasid. Jika syarat tersebut dihapuskan,transaksinya bisa menjadi sah. Kedelapan, Teori Tawabi. Dalam kaidah fiqh: “ at-tabi'u tabi',"(sesuatu yang mengikat [menempel pada sesuatu] hukumnya mengikat pada sesuatu).Oleh karena suatu benda yang mengikat pada benda lain,hukumnya juga mengikat pada sesuatu yang mengikat induk tersebut. Meskipun tidak disebutkan secara spesifik ketika akad dilaksanakan. Kesembilan, Teori Jaminan (Nadhariyat AlDhaman). Bermula dari masalah kharaj yang diartikan sesuatu yang dihasilkan atau output dari sesuatu yang diperihalah,dijaga ataupun dipergunakan karena menjaga harta atau barang milik orang lain. Dalam kaidah, " al-kharaj bi dhaman" (kharaj itu diikat dengan tanggungan).

Tabel 1.2. Tinjauan hukum zakat menggunakan teknologi digital

\begin{tabular}{|c|c|c|}
\hline Teori/kaidah & $\begin{array}{l}\text { Fintech in zakat } \\
\text { payment }\end{array}$ & Hasil analisis \\
\hline $\begin{array}{l}\text { 1. Niat } \\
\text { (Nadharariya } \\
\text { t An-Niyat) }\end{array}$ & $\begin{array}{lr}\text { Digitalisasi } & \text { zakat } \\
\text { digunakan } & \text { dalam } \\
\text { proses penghimpunan } \\
\text { dana, penyaluran } \\
\text { zakat, pengelolaan } \\
\text { zakat dan sarana } \\
\text { edukasi zakat }\end{array}$ & $\begin{array}{l}\text { Tindakan BAZNAS sesuai dengan } \\
\text { kepustakaan hukum syariah. } \\
\text { Akan tetapi kaidah niat tidak } \\
\text { dapat digunakan untuk } \\
\text { membahas tindakan pembayaran } \\
\text { zakat digital oleh muzakki, } \\
\text { karena tidak diketahui apakah } \\
\text { ada Lafadz yang diucapkan } \\
\text { ketika menggunakan teknologi } \\
\text { digital, sehingga tidak bisa } \\
\text { dijadikan sandaran hukum yang } \\
\text { mengikat kedua belah pihak. } \\
\text { Sedangkan pada ATM beras yaitu } \\
\text { penyaluran zakat terhadap } \\
\text { mustahik, pengelola langsung } \\
\text { memberikan ATM tersebut } \\
\text { kepada yang berhak menerima } \\
\text { sehingga secara hukum dianggap } \\
\text { sah. }\end{array}$ \\
\hline $\begin{array}{l}\text { 2. Ungkapan } \\
\text { Keinginan }\end{array}$ & $\begin{array}{l}\text { Pembayaran } \\
\text { menggunakan }\end{array}$ & $\begin{array}{l}\text { Keinginan hati tampak jelas } \\
\text { ketika muzakki menggunakan } e \text { - }\end{array}$ \\
\hline
\end{tabular}

${ }^{30}$ BAZNAS, 2019, Op., cit, hlm. 3. 


\begin{tabular}{|c|c|c|}
\hline $\begin{array}{l}\text { (Nadhariya } \\
\text { Al-Ta'bir Al- } \\
\text { 'Iradat) }\end{array}$ & commerce & $\begin{array}{l}\text { commerce untuk tujuan } \mathrm{ZIS} \text {, hal } \\
\text { ini berarti pembayaran zakat sah } \\
\text { karena adanya tanda yang } \\
\text { menunjukkan keinginan hati } \\
\text { (iradah) }\end{array}$ \\
\hline $\begin{array}{l}\text { 3. Pemeliharaan } \\
\text { Kemaslahata } \\
\text { n (Nadhariya } \\
\text { Al-Maslahah) }\end{array}$ & $\begin{array}{lr}\text { Digitalisasi } & \text { zakat } \\
\text { digunakan } & \text { untuk } \\
\text { memberikan } & \\
\text { kemudahan } & \text { transaksi } \\
\text { zakat } & \end{array}$ & $\begin{array}{l}\text { Selama tidak menyebabkan } \\
\text { kemudaratan, maka digitalisasi } \\
\text { zakat dapat menciptakan } \\
\text { maslahat yang diterima oleh } \\
\text { syariah Islam }\end{array}$ \\
\hline $\begin{array}{l}\text { 4. Hukum Asal } \\
\text { (Nadhariyat } \\
\text { Al-Akhdzi bi } \\
\text { Al-Istihab) }\end{array}$ & $\begin{array}{l}\text { Zakat payment digital } \\
\text { merupakan alat untuk } \\
\text { mempermudah } \\
\text { transaksi pembayaran } \\
\text { zakat ,amil lebih } \\
\text { tertata melakukan } \\
\text { pengelolaan } \\
\text { membantu masyarakat } \\
\text { untuk menghitung } \\
\text { jumlah zakatnya dan } \\
\text { mustahik lebih cepat } \\
\text { menerima manfaatnya }\end{array}$ & $\begin{array}{l}\text { Zakat payment digital hanyalah } \\
\text { sebagai alat, tidak ada akad } \\
\text { yang mengikat muzakki dan } \\
\text { mustahik secara hukum. Apabila } \\
\text { timbul keraguan atau dugaan } \\
\text { adanya penyalahgunaan zakat. } \\
\text { Maka tidak wajib mengganti } \\
\text { zakat tersebut kecuali ada unsur } \\
\text { kesengajaan yang menyebabkan } \\
\text { kerugian materil secara hukum. } \\
\text { Karena pada hakikatnya BAZNAS } \\
\text { hanya memenuhi amanah (yad } \\
\text { amanah) dan muztahik sebagai } \\
\text { yang berhak menerima zakat. } \\
\text { Dengan bukti bahwa muzakki } \\
\text { menggunakan Fintech sebagai } \\
\text { alat sah pembayaran ZIS } \\
\text { sehingga tidak dapat dibatalkan } \\
\text { dengan datangnya keraguan. }\end{array}$ \\
\hline $\begin{array}{l}\text { 5. Batasan- } \\
\text { batasan } \\
\text { ljtihad } \\
\text { (Nadhariyat } \\
\text { Dhawabith } \\
\text { Al-Ijtihad) }\end{array}$ & $\begin{array}{l}\text { Kemajuan teknologi } \\
\text { memunculkan lahirnya } \\
\text { Digitalisasi zakat }\end{array}$ & $\begin{array}{l}\text { Abdul Wahab } \begin{array}{r}\text { Khallaf } \\
\text { tentang }\end{array} \\
\text { kenjelaskan } \\
\text { kemajuan tegnologi. Dari Fatwa } \\
\text { tentang Uang Elektronik Syariah } \\
\text { No. 116/DSN-MUI/IX/2017 dan } \\
\text { Fatwa tentang Layanan } \\
\text { Pembiayaan } \\
\text { Berbasis Teknologi Informasi } \\
\text { Berbasis Syariah (Fatwa No. } \\
\text { 117/DSN-MUI/IX/2018) maka }\end{array}$ \\
\hline
\end{tabular}




\begin{tabular}{|c|c|c|}
\hline & & $\begin{array}{l}\text { diperoleh ijma bahwa Fintech in } \\
\text { zakat payment hukumnya } \\
\text { diperbolehkan }\end{array}$ \\
\hline $\begin{array}{l}\text { 6. Perwalian } \\
\text { (Nadhariyat } \\
\text { Al-Walayah) }\end{array}$ & $\begin{array}{lr}\text { Teknologi } & \text { Blackchain } \\
\text { digunakan } & \text { untuk } \\
\text { meningkatkan } & \\
\text { transparansi } & \text { lembaga } \\
\text { pengelola } & \text { zakat. } \\
\text { Diharapkan } & \\
\text { meningkatkan } & \\
\text { kepercayaan } & \text { muzaki } \\
\text { dalam menyalurkan } \\
\text { zakatnya } \\
\text { BAZNAS. }\end{array}$ & 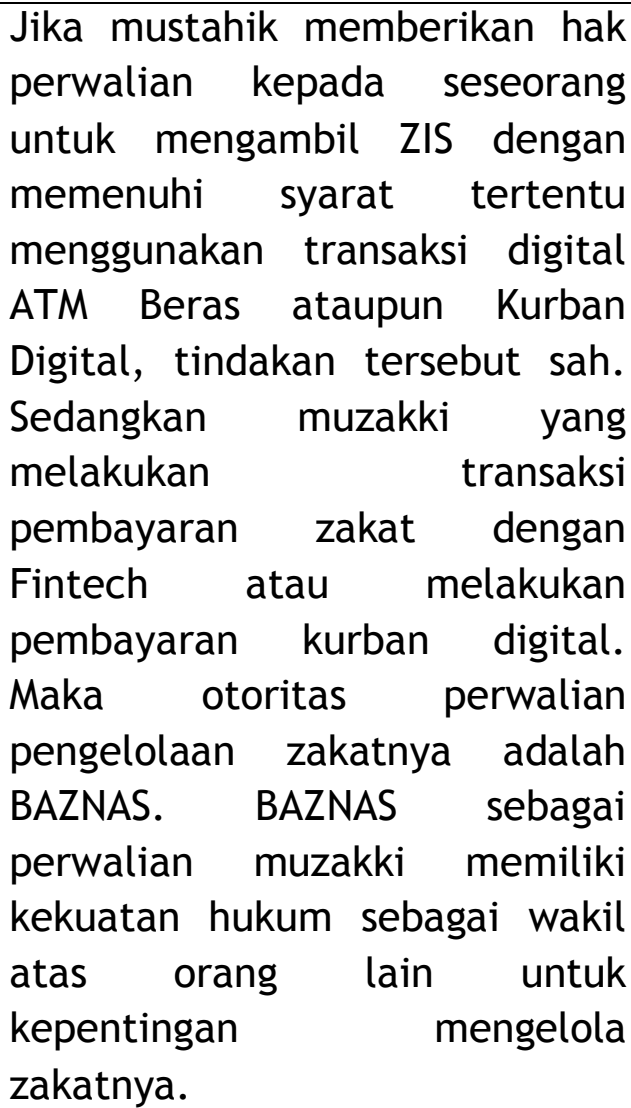 \\
\hline $\begin{array}{l}\text { 7. Syarat } \\
\text { Jaliyah } \\
\text { dalam Akad }\end{array}$ & $\begin{array}{l}\text { Digitalisasi zakat } \\
\text { dengan menghimpun } \\
\text { zakat melalui Cashless } \\
\text { yaitu kemudahan } \\
\text { bertransaksi } \\
\text { menggunakan ponsel. } \\
\text { Semakin banyaknya } \\
\text { masyarakat } \\
\text { menggunakan cashless } \\
\text { dan social media. }\end{array}$ & $\begin{array}{l}\text { Syarat Jaliyah tidak dapat } \\
\text { sepenuhnya digunakan dalam } \\
\text { Fintech in Zakat Payment, } \\
\text { dikarenakan tidak ada } \\
\text { kesepakatan atas ketentuan } \\
\text { yang ditetapkan kedua belah } \\
\text { pihak. Akan tetapi seiring } \\
\text { kemajuan teknologi dan menjadi } \\
\text { tradisi dan kebiasaan , } \\
\text { menggunakan Fintech dianggap } \\
\text { memenuhi syarat dan hukum } \\
\text { transaksinya sah. }\end{array}$ \\
\hline 8. Tawabi & $\begin{array}{l}\text { e-commerce } \\
\text { digunakan sebagai } \\
\text { kanal pembayaran. } \\
\text { Dimana muzaki dapat } \\
\text { melakukan }\end{array}$ & $\begin{array}{lrr}\text { Pembayaran } & \text { ZIS } & \text { dan } \\
\text { pembelajaan } & & \text { daring } \\
\text { menggunakan } & \text { e-commerce } \\
\text { adalah dua transaksi yang } \\
\text { memiliki tujuan berbeda }\end{array}$ \\
\hline
\end{tabular}




\begin{tabular}{|l|l|l|}
\hline & $\begin{array}{l}\text { pembayaran ZIS } \\
\text { sembari melakukan } \\
\text { pembelanjaan daring. }\end{array}$ & $\begin{array}{l}\text { walaupun menggunakan satu } \\
\text { kanal pembayaran yang sama. } \\
\text { Sehingga hukumnya tidak } \\
\text { mengikat antara satu dengan } \\
\text { yang lainnya. }\end{array}$ \\
$\begin{array}{l}\text { 9. Jaminan } \\
\text { (Nadhariyat }\end{array}$ & $\begin{array}{l}\text { Tidak ada jaminan } \\
\text { terhadap transaksi } \\
\text { pembayaran } \\
\text { menggunakan Fintech. }\end{array}$ & $\begin{array}{l}\text { Fintech in Zakat Payment } \\
\text { bukanlah trasanksi pembayaran } \\
\text { perdagangan atau pun } \\
\text { perniagaan. Maka tidak berlaku } \\
\text { kharaj untuk BAZNAS dan tidak } \\
\text { ada jaminan pengembalian } \\
\text { apabila terjadi kelalaian } \\
\text { ataupun kesalahan pada saat } \\
\text { transaksi Fintech }\end{array}$ \\
\hline
\end{tabular}

Sumber: Utami et al, $2019^{31}$

Dari hasil penelitian Utami dan Julianas tersebut mengindentifikasikan beberapa kelemahan teknologi digital dalam pembayaran zakat BAZNAS, diantaranya:

a) Niat (Nadharariyat An-Niyat) tidak dapat menjadi sandaran hukum yang mengikat dari pihak muzakki,pengelola ataupun mustahik yang menerima ZIS. Aspek yang tampak jelas adalah, tidak adanya jaminan 100\% bahwa ZIS yang telah diterima mustahik akan semaksimal mungkin digunakan untuk memenuhi kebutuhan hidupnya. Hal ini disebabkan ungkapan keinginan (Nadhariya Al-Ta'bir Al-'Iradat) bisa saja tersembunyi. Karena pada hakikatnya keinginan dalam hati itu bisa saja karena keinginan hawa nafsu atau bisa jadi keinginan karena kebutuhan hidup. Keduanya jelas memiliki tujuan yang berbeda.

b) Penggunaan teknologi digital dalam transaksi pembayaran zakat jelas memiliki tujuan syariat Allah SWT. Artinya, ada kemaslahatan sehingga dapat diterima penggunanya selama dengan syarat tidak terdapat kemudharatan atas penggunaan Fintech tersebut. Fintech hanyalah alat pembayaran, karenanya tidak adanya ketentuan hukum yang mengharuskan penggantian zakat oleh BAZNAS yang diberikan muzakki melalui Fintech apabila terjadi penurunan tingkat kesejahteraan mustahik. Mustahik juga tidak terikat hukum, apabila setelah menerima zakat produktif,ternyata kesejahteraanya tidak meningkat.

${ }^{31}$ Pertiwi Utami, et al. (2019). Op., cit 
c) Teknologi digital yang digunakan BAZNAS untuk memperoleh zakat dari muzzaki sesuai untuk kepentingan dari tujuan zakat. Akan tetapi apabila dalam penggunaan teknologi digital ternyata terdapat syarat-syarat yang membebankan muzakki ataupun mustahik, maka hukum transaksinya bisa menjadi fasid (tidak sah). Dikeluarkannya sertifikasi halal oleh MUI terhadap transaksi pembayaran zakat menggunakan Fintech, tidak dapat menjamin secara keseluruhan bahwa transaksi tersebut aman, terpercaya dan syari'.Menurut OJK (2019), “Penggunaan Fintech rentan terjadi penyalahgunaan data, peretas, dan penipuan."

Dan dapat disimpulkan bahwa hukum teknologi digital itu sendiri diperbolehkan, selama tidak bertentangan dengan prinsip-prinsip syariah serta tidak mengandung unsur-unsur kemudharatan. ${ }^{32}$ Selanjutnya adalah dengan menerapkan prinsip dalam manajemen Ekonomi Syariah adalah akuntanbilitas dan transparansi dengan menggunakan teknologi. Manajemen operasional ini telah dilakukan oleh BAZNAS Pusat. Namun belum maksimal, karena dari hasil studi dokumentasi BAZNAS peneliti masih melihat ada file laporan keuangan salah format sehingga dibutuhkan aplikasi untuk penyampaian laporan keuangan yang lebih baik lagi.

Dalam standar akuntansi syariah perusahaan nirlaba sekalipun tentu memiliki pengeluaran operasional dan beban oleh karena itu Standar Akuntansi Syariah dan regulasi standarisasi dalam upaya menjamin pengelolaan zakat harus digunakan. Namun kembali lagi bahwa inovasi teknologi atau IT masih kurang. Bahkan penggunaan blockchain, media interned based dalam sosialisasi program dan akuntabilitas disejumlah BAZNAS wilayah masih rendah. Hal ini terkait dengan beban operasional yang harus dikeluarkan oleh BAZNAS dan jaringan internet di Indonesia yang memang masih sangat rendah dibandingkan dengan negara lain.

Jaringan internet yang lemah dapat mengganggu implementasi digital zakat terutama memasuki bulan Ramadhan dimana jumlah muzzaki akan meningkat lebih dari 100\%. Akan terjadi error, karena jaringan dan server tidak mendukung. Teknologi dapat digunakan untuk mengelola data penerimaan dan pengeluaran BAZNAS secara lebih profesional, meminimalisir 'kesenjangan harapan', meminimalisir tindak auditing kecurangan serta dapat digunakan sebagai audit digital internal BAZNAS dan masyarakat juga dapat mengakses dengan mudah dan lebih. Untuk mengurangi biaya yang besar dari penggunaan teknologi yang semakin muktahir, gagasan untuk membangun tata kelola Amil Zakat yang baik dengan transparansi dan partisipasi kelembagaan dapat dilakukan.

32 Ibid. 


\section{Penutup}

\section{Simpulan}

Pengelolaan zakat digital Digitalisisasi pembayaran zakat pada Badan Amil Zakat Nasional dilakukan dengan marketing strategy dan sudah sesuai dengan kaidah hukum Islam. Percepatan sosialisasi dilakukan kerjasama dengan mitra digital seperti toko virtual dan perusahaan yang menggunakan vitur online lainnya seperti Wisata Muslim, Gopay, dan Cimb Niaga Syariah dalam upaya memberikan kemudahan kepada muzzaki membayar zakat kapanpun dan dimanapun. Dengan demikian, refleksi payment digital zakat akan mampu meningkatkan potensi penerimaan zakat dan memberikan kesejahteraan kepada mustahiknya.

\section{Saran}

Kepada Badan Amil Zakat Nasional terus melakukan upaya terobosan digital sehingga berdampak untuk meningkatkan kesejahteraan masyarakat. Dari segi hukum ekonomi dan keuangan syariah teknologi digital kiranya dapat dilakukan pada bank syariah secara masif dalam upaya sosialisasi zakat digital yang digunakan sebagai alat transaksi pembayaran dan penerimaan zakat dalam upaya mencapai prinsip-prinsip syariah dalam pengelolaan harta.

\section{Daftar Pustaka}

\section{Buku}

Andri Soemitra, Bank Dan Lembaga Keuangan Syariah Edisi Kedua. Depok: Kencana, 2017.

Amir Syariffuddin, Ushul Fiqh Jilid 1 Edisi Pertama, Kencana, Jakarta, 2014. Juhaya S. Pradja, Ekonomi Syariah, CV. Pustaka Setia, Bandung, 2012.

Muhammad, Metodologi Penelitian Ekonomi Islam: Pendekatan Kuantitatif. Rajawali Pers, Jakarta, 2008.

\section{Artikel/Karya Ilmiah:}

Ak Md, Hasnol Alwee Pg, 'Integrating Financial Inclusion and Saving Motives into Institutional Zakat Practices: A Case Study on Brunei', International Journal of Islamic and Middle Eastern Finance and Management, 8 (2015), 150-70. https: // doi.org/10.1108/17538391111144515.

Ahmad RAR, Othman AMA, Salleh MS. Assessing the Satisfaction Level of Zakat Recipients Towards Zakat Management. Procedia Econ Financ. 2015;31(15):140-151. doi:10.1016/s2212-5671(15)01141-7

BAZNAS, Divisi Riset dan Kajian Pusat Kajian Strategis, Dampak Zakat Terhadap Kesejahteraan Mustahik: Evaluasi Program Zakat Produktif 2018, ed. by Pusat Kajian Strategis BAZNAS (Jakarta Pusat, 2019)

---, Outlook Zakat Indonesia 2019, 2019

---, Outlook Zakat Indonesia 2020, 2020

Divisi Riset dan Kajian Pusat Kajian Strategis BAZNAS, Dampak Zakat Terhadap 
Kesejahteraan Mustahik: Evaluasi Program Zakat Produktif 2018, ed. by Pusat Kajian Strategis BAZNAS (Jakarta Pusat, 2019).

Dian Friantoro, and Khozin Zaki, 'Do We Need Financial Technology for Collecting Zakat?', International Conference of Zakat 2018 Proceedings, 2018, 227-38

Doktoralina, Caturida Meiwanto, Zakaria Bahari, and Sakinatul Raadiyah Abdullah, 'Mobilisation of Income Zakat Payment In Indonesia', IKONOMIKA: Jurnal Ekonomi Dan Bisnis Islam, 3 (2018), 189-204

Fares Djafri, 'Fintech and Islamic Finance: Aplying Hiyal \& Makhrij and Other Islamic Principles', 2018, 1-10 https: //www.researchgate.net/publication/325333580\%0AFintech.

M. Aulia Rachman, and Annisa Nur Salam, 'The Reinforcement of Zakat ManagementthroughFinancial Technology Systems', InternationalJournal $\begin{array}{llll}\text { of } & \text { Zakat, } & \text { 57-69. }\end{array}$ http://ijazbaznas.com/index.php/journal/article/view/68/32.

Natalia Monjelat, and Siti Jamila, 'Analisis Efisiensi \& Efektivitas Zakat Payroll System Dan Zakat Digital Terhadap Penerimaan Zakat Pada BAZNAS Periode 2016-2017', Director, 2018, 1-104. https: / / doi.org/10.22201/fq.18708404e.2004.3.66178.

Prahesti DD, Pemberdayaan Usaha Kecil dan Mikro Melalui Dana Zakat Produktif, Acad J Homilet Stud. 2018;12(1):141-160, doi:10.15575/idajhs.v12i.190.

Pertiwi Utami \& Julianas, D. Management of Zakat Payment Based on Fintech for the Good Corporate Governance Improvement. Eastern Journal of Economics and Finance, 4(2), (2019). 41-50.

S.N. Naqvi H. Islamic Economic Methodology in A.R Moten and B. Shari (eds). Nature and Methodology of Islamic Economic. Bayero University. Nigeria. (1981).

Smith, Adam, 'Emergence of Fintech and Cybersecurity in a Global Financial Centre: Strategic Approch by a Regulator', Journal of Financial Regulation and Compliance, 16 (2014). https: //doi.org/10.1108/jfrc.2008.31116baa.001.

Wahyu Syuryana \& Dwi Murdaningsih. Alasan Pentingnya Digitalisasi Zakat, Khazanah, 2018. Diakses dari https: / / www.republika.co.id/berita/duniaislam/ wakaf /18/11/15/pi83kx368-alasan-pentingnya-digitalisasizakat, Pada tanggal 2525 juli 2019.

\section{Peraturan Perundang-Undangan:}

Undang-Undang Nomor 23 Tahun 2011 Tentang Pengelolaan Zakat

Undang-Undang Republik Indonesia Nomor 19 Tahun 2016 Tentang Informasi dan Transaksi Elektronik 